\title{
Asertywność jako istotna kompetencja społeczna w rzeczywistości szkolnej uczniów
}

\section{KEYWORDS}

assertiveness, student, non-assertive behaviour, assertive behaviour

\begin{abstract}
Kaźmierska Marlena, Asertywność jako istotna kompetencja społeczna w rzeczywistości szkolnej uczniów [Assertiveness as an important social competence in the school reality of students]. Kultura - Społeczeństwo - Edukacja nr 1(13) 2018, Poznań 2018, pp. 169-180, Adam Mickiewicz University Press. ISSN 2300-0422. DOI 10.14746/kse.2018.13.13.

The main aim o the article is to highlight the devolopment of assertiveness in students. The article presents concepts of social skills and assertiveness. In emphasizes the issue of non-assertive behaviour in education. Next the article describes the value of assertiveness skills to the life of the student and it presents to teachers methods for teaching assertiveness to children.
\end{abstract}

\section{Wstęp}

Współczesna rzeczywistość społeczno-kulturowa, cechująca się intensywną dynamiką zmian, wymusza ciągłą aktualizację wiedzy oraz umiejętności z zakresu działań psychospołecznych i socjopedagogicznych. Jednym z obszarów, na którym ta konieczność rysuje się szczególnie wyraźnie, jest funkcjonowanie jednostek $\mathrm{w}$ podstawowych środowiskach socjalizacyjnych, w tym również w środowisku szkolnym. Obecnie przed edukacją stoi niezwykle ważne i trudne zadanie: rozwijać u każdego ucznia zdolności społeczne, które można ukształtować metodami stymulacyjnymi, jak również treningiem społecznym. Jedną z tego rodzaju zdolności jest asertywność. Ta właśnie kategoria stanowi zasadniczy przedmiot rozważań podjętych w niniejszym artykule. 


\section{Kompetencje społeczne - dookreślenie pojęcia}

Asertywność jest rodzajem kompetencji społecznych ujmowanych wielowątkowo oraz niejednoznacznie. Jako pierwszy termin zdolności społecznych wprowadził Robert White w 1959 roku. Zajmował się on tematyką wywierania wpływu na środowisko społeczne. Rozumiał „kompetencje” jako swoistą umiejętność, która doprowadza do efektywnej interakcji z otoczeniem. W ten sposób powiązał kompetencje z umiejętnościami społecznymi.

Według Michaela Argylea kompetencje społeczne to: „zdolność, posiadanie niezbędnych umiejętności do tego, by wywrzeć pożądany wpływ na innych ludzi w sytuacjach społecznych. Te pożądane wpływy mogą polegać na skłonieniu innych do kupna, do nauki, do pozyskania zdrowia psychicznego" (Argyle, 2002: 133). Z kolei Anna Matczak definiuje niniejszy termin jako: „złożone umiejętności warunkujące efektywność radzenia sobie w określonego typu sytuacjach społecznych, nabywane przez jednostkę w toku treningu społecznego" (Markowska, 2012: 15). Natomiast w ujęciu Braina Spitzberga i Williama Cupacha kompetencje społeczne to zdolność budowania więzi emocjonalnych z innymi ludźmi ujmowana w kategorię definiowania relacji, tworzenia, rozwijania i utrzymywania związków oraz uzyskiwania społecznego poparcia (Szymańska, 2012: 11).

Kompetencje społeczne składają się z wielu umiejętności interpersonalnych i intrapersonalnych. Według M. Agryle’a można je podzielić ze względu na cechy oraz określone zachowania wyróżniające jednostkę kompetentną społecznie. Składają się na nie: asertywność, będąca zdolnością wywierania wpływu na innych (stanowiąca równocześnie przeciwieństwo agresji i biernego zachowania), jak również gratyfikacja, czyli efekt wsparcia w sytuacjach społecznych, który polega na podtrzymywaniu innych oraz zwiększaniu poczucia ich własnej wartości. Werbalne i niewerbalne komunikowanie się również stanowi przykład umiejętności społecznych wynikających z cech osobowych podmiotu. Komunikacja werbalna stanowi umiejętność społeczną o kluczowym znaczeniu, ponieważ większość sygnałów jest werbalna i musi się mieścić w sekwencji konwersatoryjnej, co oznacza, iż każdy komunikat musi być zrozumiały dla odbiorcy. Komunikacja niewerbalna jest jej dopełnieniem, bowiem wyraża się w określonego rodzaju gestach, mimice twarzy i postawie ciała.

Kolejnymi składowymi kompetencji społecznych są: empatia, współpraca i uwaga skoncentrowana na innych. Empatia jest zdolnością dzielenia emocji odczuwanych przez inną osobę i rozumienia jej punktu widzenia, rozumienia sytuacji drugiego człowieka. Kategoria empatii jest również związana z umiejętnością współpracy. Istotą efektywnej współpracy jest jednoczesne uwzględnianie potrzeb 
własnych, jak również innych członków interakcji. Każdy rodzaj aktywności społecznej wymaga nawiązania wzajemnej relacji międzyludzkiej, a zatem nie bez znaczenia jest umiejętność współpracy z innymi.

Istotnym elementem kompetencji społecznych jest również poznawanie i rozwiązywanie problemów. W tej sferze zasadniczą rolę odgrywają tak zwane kompetencje miękkie.

Nie bez znaczenia dla uczniów jest również zdolność autoprezentacji, która dotyczy związku kompetencji społecznych z oceną ,ja” osób wchodzących w interakcje, jak również sposobu reagowania na zachowania innych. Własny wizerunek jest zbiorem pojęć, jakie dana jednostka ma na własny temat, takie jak odgrywane role społeczne, cechy charakteru i wyglądu zewnętrznego. Prezentowanie siebie jest zachowaniem mającym na celu wywieranie wpływu na to, w jaki sposób widzą nas inni.

Kolejnym elementem kompetencji społecznych są zdolności związane z cechami osobowości, na przykład bezpośredniość (Kanios, 2010: 13-21).

Asertywność wymaga opanowania takich umiejętności jak: komunikacja werbalna i niewerbalna, autoprezentacja, poznawanie i rozwiązywanie problemów oraz posiadanie zdolności w różnych sytuacjach i związkach.

\section{Asertywność jako złożona kompetencja społeczna - rozważania teoretyczne}

Termin „asertywność” pochodzi od słowa „assertive”, który rozumiany jest jako: „sposób zachowania polegający na stanowczym, mocnym, pewnym siebie wyrażaniu własnych emocji lub praw i ujawnianiu na zewnątrz głębokiej wiary we własne umiejętności (...) pewne siebie zachowanie się, które wywołuje szacunek innych ludzi" (Poprawa, 2000: 106-107).

W ujęciu Heleny Sęk asertywność to „złożony zespół kompetencji osobistych polegających na skutecznym dochodzeniu do ważnych celów życiowych, przy równoczesnym, stałym potwierdzaniu i obronie pozytywnego samoobrazu" (Sęk, 1988: 795). Z kolei Nathaniel Barden asertywność rozumie jako respektowanie własnych potrzeb, pragnień i wartości; poszukiwanie własnych dróg wyrażania ich w życiu codziennym (Branden, 1998: 133-135). Natomiast Maria Król-Kijewska podkreśla, iż asertywność to umiejętność ujawniania i wyrażania siebie w kontakcie z drugim człowiekiem. Nie odnosi się ona tylko w relacjach interpersonalnych, ale do swoistego sposobu myślenia jednostki (Król-Fijewska, 1992: 23).

Zgodnie z koncepcją Richarda Lazarusa asertywność składa się z czterech komponentów: odrzucanie próśb, zwracanie się z prośbą i wydawanie poleceń, 
wyrażanie uczuć pozytywnych i negatywnych oraz rozpoczynanie, kontynuowanie i kończenie ogólnej rozmowy. Lazarus zwrócił uwagę na korelację asertywności z wieloma elementami komunikacji werbalnej i niewerbalnej. Istotą każdej formy oddziaływania społecznego jest życzenie werbalne. Jeśli ma być skuteczne, to musi być przekonujące, czyli powinno się motywować i nakłaniać przez wskazywanie słusznych powodów lub zachęt do wykonywania polecenia. Poleceniom słownym musi towarzyszyć odpowiedni styl niewerbalny. Oddziaływanie jest większe, kiedy istnieje już silna więź przyjaźni, autorytet lub oba równocześnie (za: Argyle, 2002: 114).

Asertywność to umiejętność, która przejawia się zachowaniem asertywnym, polegającym na adekwatnym (tzn. pozostającym w zgodzie ze samym sobą), otwartym, stanowczym, uczciwym, ale kontrolowanym wyrażeniu własnej opinii, czyli autoekspresji swoich przekonań, postaw, potrzeb, emocji oraz realizacji i radzeniu sobie z wymaganiami własnych relacji życiowych, przy równoczesnym poszanowaniu, respektowaniu dóbr osobistych innych ludzi włączanych w te relacje (Poprawa, 2000: 114).

Sposób ujawniania zachowań asertywnych zależy od wielu czynników. Podstawowe znaczenie dla zdecydowania o wyborze właściwego zachowania ma charakter sytuacji, w jakiej znalazła się jednostka, jej wiedza o tym, jak powinno się zachować w określonych okolicznościach, a także typ interakcji z partnerem lub partnerami relacji.

Ze względu na sposób ujawniania się asertywności H. Sęk wyróżniła trzy rodzaje umiejętności asertywnych. Pierwsze z nich to umiejętności ekspresyjne, do których należy wyrażanie emocji i pragnień za pomocą języka werbalnego i niewerbalnego. Wyszczególnione zostały również umiejętności interpersonalne, do których należą między innymi: komunikowanie się, prośby o wsparcie, rozpoczynanie relacji, reakcje na oceny i pochwały, obrona własnego zdania i odmawianie. Istotne są również umiejętności zadaniowe, na przykład dowodzenie własnych praw, obrona poszkodowanego, zdobywanie potrzebnych środków do realizacji celów, pokonywanie przeszkód, realizacja przełomowych pomysłów (Sęk, 1988: 797). Zachowania asertywne mają za zadanie obronę i rozwój „ja” oraz skuteczną realizację własnych pomysłów i wartości, nie mogą naruszać dobra innych ludzi.

Joseph Wolpe wyróżnił asertywność pozytywną - „chwaloną” i negatywną „wrogą". Przykładem pierwszej jest wyrażenie podziękowania, a drugiej - niezadowolenia. Na podstawie niniejszego podziału Eileen Grambrill oparła klasyfikację zachowań asertywnych. Autorka wymieniła dwa główne aspekty asertywności: po pierwsze to, czy zachowanie jest pozytywne czy negatywne, a po drugie - czy zachowanie inicjowane jest przez jednostkę, czy jest odpowiedzią na zachowanie 
kogoś drugiego. Rozgraniczyła w ten sposób cztery główne rodzaje asertywności, z których każdy obejmuje kilka szczegółowych kategorii.

Pierwszą jest negatywna asercja w odpowiedzi na to, gdy ktoś inny podejmuje inicjatywę, czyli umiejętność powiedzenia "nie” wobec żądania, którego jednostka nie może spełnić. Składają się na nią następujące zachowania: odmowa wobec żądań i reakcja na krytykę.

Drugą jest negatywna asercja łącząca się z podejmowaniem inicjatywy, polegająca na przejęciu inicjatywy w celu wywołania zmiany w otoczeniu. Możliwe są tu następujące rodzaje zachowań: żądanie zmiany obraźliwego zachowania kogoś drugiego lub niesprawiedliwego traktowania; obrona przed przerywaniem wypowiedzi lub czynności; przeproszenie, kiedy jest się winnym, które wymaga przejęcia inicjatywy sytuacji niezręcznej dla jednostki; przyznanie się do niewiedzy oraz kończenie niepożądanych interakcji.

Kolejną jest pozytywna asercja, gdy inicjatywę przejmuje ktoś inny. Społeczne interakcje wymagają niejednokrotnie pozytywnej asercji, która jest odpowiedzią na inicjatywę drugiej osoby. W niniejszym przypadku istnieje kilka możliwych kategorii asertywnego zachowania: akceptowanie komplementów; reakcja na inicjatywę drugiej osoby oraz przyjęcie zaproszenia lub odpowiedź na propozycję spotkania.

Można również wyróżnić „wychodzenie naprzeciw”, czyli podejmowanie inicjatywy. Ten rodzaj asertywności obejmuje także kilka podkategorii: rozpoczynanie rozmowy; podtrzymywanie rozmowy; aranżowanie przyszłych kontaktów i kończenie rozmów; prośba o przysługę; mówienie innym komplementów oraz okazywanie emocji (Rejniak, 2008).

Przeciwieństwem zachowań asertywnych są zachowania nieasertywne, określane również jako pasywne lub submisyjne. Ich przyczyną jest brak wiary człowieka w możliwość posiadania własnych przekonań, wyborów, odczuć.

Kolejnym powodem braku asertywności są procesy socjalizacji dziecka, które uczą kontrolowania negatywnych uczuć i zmuszają do powstrzymania ujawniania ich w kontaktach międzyludzkich. Obecnie polskie szkoły wychowują kolejne pokolenia uczniów podporządkowanych i uległych. Nagradzani są wychowankowie posłuszni i ulegli, a zbuntowani i uparci, którzy mają odwagę głośno wypowiedzieć własne poglądy, są karani. Także takie zachowanie jest skutkiem nieodpowiednich nawyków kulturowych, które popierają zachowania cechujące się zależnością i skromnością. Kolejną przyczyną braku gotowości do obrony własnych praw i otwartego wyrażania siebie są czynniki społeczno-ekonomiczne. Chodzi tu z jednej strony o lękliwość rodziców, która wywołuje w wyniku modelowania lękliwość u dziecka, a z drugiej strony posługiwanie się 
wzorem dziecka skromnego, zależnego, nie bez znaczenia są również negatywne postawy wychowawcze (Zubrzycka-Maciąg, 2011: 147). Celem zachowania pasywnego jest unikanie bezpośredniej konfrontacji i konfliktów, które wiążą się z doświadczaniem niechęci lub gniewu ze strony społeczeństwa (Mączyński, 1993: 621).

\section{Asertywność - implikacje w edukacji i wychowaniu}

Obecnie w edukacji można zauważyć dążenie, by uczeń stał się jednostką samodzielną i autonomiczną. Takie założenie towarzyszy od samego początku edukacji dziecka. Na pewnym etapie rozwoju jednostka osiąga taką autonomię i samodzielność w działaniu, myśleniu, przeżywaniu i dokonywaniu wyborów.

Asertywność jest istotną umiejętnością, by odgrywać satysfakcjonujące role społeczne, ale by również być samodzielną i autonomiczną jednostką. Wielu nauczycieli zaniedbuje ten aspekt, jakże ważny w rozwoju młodego człowieka. Przyczyn takiego zachowania pedagogów jest wiele i są one niejednoznaczne. Z jednej strony jest to nieświadomość i wynikające z tego zaniedbanie tejże zdolności społecznej, z drugiej brak chęci i czasu na kształtowanie asertywności. Łatwiej nauczycielowi zapanować nad klasą, gdy uczniowie są ulegli i nie wykazują postaw asertywnych. Kolejną z przyczyn jest brak u niektórych nauczycieli asertywności; nie radzą sobie z uczniami, wymagają niezbędnego minimum lub nawet tego nie potrafią uzyskać, poddając się „rządom” uczniów.

Moim zdaniem brak rozwijania zachowań asertywnych u wychowanków jest poważnym problemem w polskiej szkole. Objawia się to $\mathrm{z}$ nieradzeniem sobie dzieci i nastolatków podczas ekspozycji społecznej, określane jako nieśmiałość. Są wyzwaniem dla nauczycieli, ponieważ wymagają poświęcenia jeszcze więcej czasu, uwagi i pracy ze strony pedagogów. Asertywność, jako wyższa kompetencja społeczna, wymaga, jak wspominałam wcześniej, opanowania niższych umiejętności, co może sprawiać nauczycielom problemy.

Nauczyciel, rozwijając asertywność u wychowanków, kreuje jednostki pewniejsze siebie i zaradniejsze, co świadczy o ich dojrzałości i mądrości społecznej. Taki pedagog rozumie potrzebę kształtowania osobowości społecznych, które, wyposażone w asertywność, łatwiej poradzą sobie w świecie permanentnej zmiany, wyzwań i chaosu. Współcześnie coraz młodsze osoby są dopuszczane do głosu, ale bez umiejętności śmiałego wyrażania swojego zdania, respektującego opinię i prawa innych, nie daje to efektów. Asertywność staje się narzędziem do wyrażania własnych potrzeb, planów i możliwości wobec starszego pokolenia. 
Asertywność jest, w mojej opinii, przejawem dojrzałości społecznej i partnerskiego, odpowiedzialnego dialogu. Nauczyciel, ignorując tę zdolność, nie dąży do całkowitej współpracy z uczniami, a raczej chce uzyskać uległość i ciszę na zajęciach. W mniemaniu wielu pedagogów o wiele trudniej jest pracować z uczniami, którzy wyrażają swoją opinię i pomysły w sposób otwarty, niż wzbudzając postrach i nie licząc się z podopiecznymi. Kształtowanie zachowań asertywnych wymaga więcej pracy od samego nauczyciela, który chce w umiejętny sposób rozwinąć tę zdolność. Mając na uwadze, iż nauczyciel jest narażony niekiedy na bezpośrednią konfrontację i sytuacje kłopotliwe, gdzie padają czasem trudne pytania lub niewygodne opinie, kształtując w ten sposób asertywność, unika tego - chcąc zachować swój pozorny autorytet. Jednak to nauczyciel, który pozostawia miejsce na dialog, niekiedy trudny i wymagający, jest bardziej doceniony przez uczniów. Pokazując różnorakie zachowania podczas komunikacji, nauczyciel staje się bliższy wychowankom; to on będzie osobą, do której zwrócą się o pomoc. Taki pedagog jest szanowany i lubiany przez młodzież, stawiany za wzór do naśladowania.

Asertywność wspomaga radzenie sobie w sytuacjach trudnych, przeciwdziała różnym zachowaniom autodestrukcyjnym i ryzykownym: uzależnieniom, uleganie wpływom nieodpowiednim osobom. Ta umiejętność jest szczególnie ważna podczas adolescencji - wtedy jest poddawana naturalnemu treningowi społecznemu. Podczas określenia ról w grupie rówieśniczej, wśród nowych znajomych, gdzie młodzi poddawani są różnym wyzwaniom. Nieoceniona jest również w trakcie procesu uniezależniania się od rodziców, gdzie adolescent ma możliwość trenowania asertywności, szczególnie w trakcie buntu młodzieńczego. Wtedy relacje między nastolatkiem a kolegami, rodzicami czy rodzeństwem są szczególnie narażone na napięcia. Młody człowiek, prezentując zachowania asertywne, wzrasta stopniowo w społeczeństwo jako autonomiczna jednostka.

Według mnie, by zwalczyć problem nieprzygotowania ucznia w życiu społecznym, należy rozpocząć od uświadamiania nauczycielom istotności asertywności w rozwoju młodego człowieka. Tym bardziej, iż współczesny świat wymaga, by być indywiduum pewnym siebie i wyrażającym się otwarcie, przebojowym i radzącym sobie z nieprzewidywalnością przyszłości. Realia, w których przyszło żyć i wzrastać, wymagają od nas wszystkich asertywności, by być szczęśliwym i żyć w zgodzie z innymi.

Ćwiczenia z asertywności umacniają pozytywny obraz samego siebie, kształtują poczucie kontroli i sprawstwa, zwiększają efektywność w kontaktach interpersonalnych. Umiejętność zachowania asertywnego jest jednym z głównych narzędzi w przeciwdziałaniu i profilaktyce uzależnień oraz innego rodzaju zachowań ryzykownych. Rozwijanie kompetencji asertywności przeciwdziała również zaburze- 
niom w zachowaniu i osobowości dziecka oraz wspiera jego rozwój. Pozwala młodej osobie na skuteczniejsze radzenie sobie w sytuacjach trudnych i pozyskanie wsparcia otoczenia.

Ważnym zadaniem dla pedagogów jest wspieranie swoich podopiecznych w osiągnięciu pełnej dojrzałości poprzez rozbudzanie ich aktywności samowychowawczej, wzmocnienie poczucia własnej wartości, samokontroli i odpowiedzialności, decydowania o osobie.

Kształtowanie postawy asertywnej jako element pracy pedagoga jest warunkiem efektywnego kształcenia. Nauczyciel darzący szacunkiem swoich uczniów, tolerujący ich, uwzględniający ich poglądy, opinie, doświadczenia, emocje i wartości tworzy sprzyjającą atmosferę, w której łatwiej jest osiągnąć sukcesy edukacyjne. Asertywny pedagog traktuje ucznia podmiotowo. Takiego nauczyciela charakteryzuje stanowczość i łagodność, nie stosuje on przemocy, agresji i manipulacji, by osiągnąć zamierzone cele edukacyjne. Postawa tego typu wychowawcy staje się wzorem do naśladowania dla uczniów. Wychowankowie chętniej i częściej korzystają z jego kompetencji społecznych, akceptują jego styl wychowawczy, czując się przy tym bezpiecznie i sprawczo (Zubrzycka-Maciąg, 2011: 143-146).

\section{Miniporadnik kształtowania umiejętności i postaw asertywnych u uczniów}

Rozwijanie asertywności nie jest łatwe, dlatego powinni się tego podejmować jedynie pedagodzy w pełni rozumiejący istotę tej umiejętności społecznej, przekonani o jej pozytywnym wpływie na psychospołeczne funkcjonowanie ucznia.

Istotne jest, aby sami nauczyciele przejawiali jak najczęściej zachowania asertywne. Należy pamiętać, że gdy wychowawca rozwija te kompetencje, musi dać odczuć dziecku, że w pełni je akceptuje i pochwala zachowania asertywne podopiecznego. Należy także udzielać wszystkim uczniom wsparcia i akceptacji, które pomoże zbudować właściwą samoocenę wychowanka.

Istnieje szereg ćwiczeń kształtujących asertywność u dzieci. Najefektywniejszym sposobem, jak podaje J. Mączyński, jest trening asertywności, który jest „zaplanowanym programem oddziaływań terapeutycznych, mających na celu redukcję agresywnego o nieasertywnego zachowania oraz modelowanie gotowości do zachowań asertywnych w różnych sytuacjach społecznych, aby jednostka mogła się nauczyć ekspresji własnych uczuć, opanowywania i wygaszania własnego lęku, kontroli nad własnym zachowaniem oraz obrony własnych praw bez naruszania praw innych ludzi” (Mączyński, 1993: 622). 
Taki trening służy osiągnięciu umiejętności swobodnego wyrażania siebie, komunikacji interpersonalnej, aktywnej postawy życiowej, bronienia własnego zdania, praw i interesów. Jego najważniejszym celem jest pomoc dziecku w rozwinięciu postawy asertywnej.

Przebieg takiego treningu wygląda następująco: na początku pedagog tłumaczy wychowankom pojęcie asertywności oraz jej istotę, następnie proponuje dzieciom ćwiczenie, które uświadamia im znaczenia posiadania własnych praw, w dalszej kolejności dzielą się oni własnymi odczuciami związanymi z udziałem w ćwiczeniu. Trening asertywności ma na celu uświadamianie powodu złego samopoczucia. Elementem ćwiczenia jest również praca domowa, która polega na sporządzeniu własnej karty praw, uwzględniajcej fakt, że nie mogą być sprzeczne z prawami innych. Na kolejnym spotkaniu dzieci wypełniają kwestionariusz asertywności, następnie pedagog dokonuje oceny, z którymi sytuacjami uczniowie mają najczęściej trudności. Każde ćwiczenie ze wszystkich rodzajów zachowań asertywnych jest poprzedzone miniwykładem, w którym opisuje się uczniom zasady i proces asertywnego reagowania. Dalej wychowankowie odgrywają scenki, podczas których nabywają zdolności i umacniają się w gotowości do przejawiania zachowań asertywnych. Kolejno osoby odgrywające poszczególne role mówią, jak się czuły w danej sytuacji. Później wspólnie uczestnicy zastanawiają się nad zachowaniem poszczególnych aktorów. Ostatnią kwestią poruszaną na treningu jest praca nad budowaniem asertywnego dialogu wewnętrznego. Po zapoznaniu się z rolą dialogu wewnętrznego pedagog zachęca uczniów do analizy rozmów wewnętrznych, aby dalej przejść do nauk zastępowania komunikatów antyasertywnych - komunikatami proasertywnymi. Wychowawca zadaje pracę domową, która kończy trening: prowadzenie autoobserwacji i samokontroli oraz posługiwanie się umiejętnościami w życiu prywatnym. Zaleca się, by zorganizować po kilku tygodniach spotkanie, które ma wesprzeć w przypadku porażki, rozwiać wątpliwości i podzielić się radością z osiągniętych sukcesów (Zubrzycka-Maciąg, 2011: 151-153).

Nabywaniu kompetencji asertywności sprzyjają doświadczenia, które wywołują określone emocje. W ten sposób skłania się jednostkę do przemyśleń nad zmianą własnych poczynań. Warto tu wykorzystać do rozwijania asertywności zajęcia arteterapeutyczne, a w szczególności: zajęcia dramowe, twórczość plastyczną i muzyczną. Uczniowie mają wtedy sposobność przeżywania różnych sytuacji społecznych poprzez wcielanie się w różne role. Lekcje tego typu stymulują umiejętność świadomego wyrażania siebie w sposób, który jest dopiero kształtowany i doskonalony podczas warsztatu arteterapeutycznego. To pozwala na pewne zaprezentowanie swojej opinii, ale bez naruszania zasad kultury i obrażania innych. 
Innym czynnikiem sprzyjającym wyzwoleniu asertywności są teksty literackie. Obcowanie z utworami literackimi przyczynia się do przetwarzania przez ucznia siebie samego, co prowadzi do pozytywnych zmian w zachowaniu, przekonań pod wpływem negatywnych lub pozytywnych przeżyć i perypetii bohaterów tekstu. Do rozwoju niniejszej zdolności pomocna jest biblioterapia z elementami dramy. Podczas zajęć podopieczny ma możliwość poznania swych słabych stron z relacjami z innymi, kształtuje umiejętność okazywania uczuć i siebie oraz konstruktywnego rozwiązywania konfliktów.

Proponuję także - na zasadzie licentia poetica - kilka rad, które być może warto zastosować w pracy z uczniami na każdych zajęciach, by stworzyć mocny fundament złożony z niższych umiejętności społecznych dla asertywności.

Po pierwsze: niech młodzi ludzie mają swobodę mówienia i w mówieniu. Należy pozostawić miejsce na swobodną dyskusję. Uczniowie poczują smak wolności, ale też otworzą się na relacje z innymi. Mogą sygnalizować ważne dla nich sprawy, problemy, tematy do rozmów. Warto organizować takie zajęcia, by każdy wypowiedział się na określony temat; nawet jeśli nie mają własnego zdania, to zapoznają się z opinią innych. Uczy to aktywnego słuchania, tolerancji, akceptacji, szacunku i zaufania.

Po drugie: niech uczniowie mówią jak najczęściej o sobie, o swoich sposobach pracy, nauki. Podopieczni, mówiąc o sobie, otwierają się na innych. Te informacje mogą być niezwykle istotne dla pedagoga, ponieważ ułatwiają postawienie trafnej diagnozy pedagogicznej. Nauczyciel może zastosować takie metody, środki, terapie, które rozbudzą i rozwiną ucznia. Dobrymi okazjami na „powiedzenie czegoś o sobie" są różne imprezy szkole, klasowe, wydarzenia, wycieczki, kółka zainteresowań itd.

Po trzecie: warto uczyć dzieci sztuki mądrej samooceny (prośba o radę kolegów, rodziców i nauczycieli). Niezwykle trudną sztuką jest właściwa samoocena, by była możliwie adekwatna - ani zbyt niska, ani zbyt wysoka. Uczenie adekwatnego oceniania własnej osoby wymaga nie lada trudu od nauczyciela. Powinien on stosować przede wszystkim pochwały, ale w umiarkowanej ilości, podawać powody, za co chwali. Winien wykorzystywać konstruktywną krytykę wobec każdego ucznia. Pomocne są także metody sprawdzające opinie innych uczniów, co sądzą o X lub Y. Warto zastosować elementy samooceny i uzasadnienia w sprawdzianach i testach.

Po czwarte: uczyć umiejętności analizowania i oceniania rozmów innych ludzi. Dziecko uczy się konstruktywnego myślenia, jego światopogląd jest poszerzany poprzez wsłuchiwanie się w rozmowy innych. Warto analizować razem z podopiecznymi ich wypowiedzi na bieżąco. Pomocne są rozmowy na temat tekstów 
literackich lub sztuki. Zmuszają one ucznia do refleksji, czy mu się podoba, czy też nie oraz wczucia się w rolę bohatera.

Po piąte: propagować i kształtować kulturę dyskusji, kształcić umiejętność obrony i negocjacji stanowiska i poglądów. Jest to bardzo trudne, ale jakże wartościowe. Pożądane jest, by mądrze organizować dyskusję, zgłębiać jej zasady i kulturę. Wtedy są doskonalone umiejętności komunikacyjne uczniów. Dyskusja zmusza do przyjęcia określonego stanowiska, jego argumentowania, wysłuchania kontrargumentów, wypracowania jakiegoś kompromisu lub wspólnego stanowiska. Uczy to także sztuki zachowań asertywnych. Należy podejmować trudne i kontrowersyjne tematy, ale interesujące uczniów, by zapoznać młodego człowieka ze sztuką rozmawiania o trudnych kwestiach, z umiejętnością rozumienia siebie i otaczającego świata. Uczeń nabywa umiejętności rozpoznawania i nazywania odczuwanych przez siebie stanów i emocji. Ułatwia to poszukiwanie źródeł własnych uczuć i sprzyja rozumieniu emocji innych, a także rozwija myślenie empatyczne. Dyskusja staje się podstawą umiejętności współdziałania i współpracy. Nauczyciel podczas dyskusji nie tylko powinien zachęcać uczniów głosem, ale i mimiką, postawą, gestem do kontynuowania i rozwijania wypowiedzi. Można także zachęcać do podejmowania nowych tematów rozmów i dyskusji, które szczególnie nurtują młodzież. Należy uczyć podopiecznych również sztuki cierpliwości, milczenia oraz doceniania wartości płynących z współdzielenia przez grupę wspólnej ciszy, Taka cisza, paradoksalnie, może być zarazem wymowna i zrozumiała (Kaźmierska, 2015: 208-209).

\section{Podsumowanie}

Umiejętność postępowania asertywnego jest jednym z postulatów współczesnych paradygmatów pedagogiki, by stworzyć z ucznia jednostkę w pełni samodzielną, dojrzałą oraz autonomiczną. Niestety, w realiach szkolnych modeluje się jednostkę, która łatwo ulega wpływom, jest zależna i pokorna. Odmienne postawy ujawniane przez uczniów są karane. Niniejsze sytuacje się zdarzają, ponieważ łatwiej i wygodniej nauczycielom jest stworzyć grzeczną, uległą i niebroniącą swoich praw osobę. Wynika to też z tego, że niewielu nauczycieli ma zdolność asertywności i pokazuje właściwe zachowania asertywne. Artykuł porusza kwestię posiadania przez ucznia tej umiejętności, która jest niezwykle istotna dla jego dalszego funkcjonowania społecznego.

W niniejszym artykule zaproponowano kilka sposobów na rozwijanie umiejętności bycia asertywnym, które można zastosować na każdych zajęciach, jednak- 